\title{
Expression of recombinant human anti-TNF-a scFv-Fc in Arabidopsis thaliana seeds
}

\author{
N. Yao*, L. Ai*, Y.Y. Dong, X.M. Liu, D.Z. Wang, N. Wang, X.W. Li, \\ F.W. Wang, XK. Li, H.Y. Li and C. Jiang \\ Ministry of Education Engineering Research Center of Bioreactor and \\ Pharmaceutical Development, Jilin Agricultural University, \\ Changchun, Ji Lin, China \\ *These authors contribute equally to this study. \\ Corresponding authors: H.Y. Li / C. Jiang \\ E-mail: hyli99@163.com / jiang_chao2015@163.com
}

Genet. Mol. Res. 15 (2): gmr.15027726

Received September 25, 2015

Accepted December 18, 2015

Published June 21, 2016

DOI http://dx.doi.org/10.4238/gmr.15027726

\begin{abstract}
Recombinant human anti-tumor necrosis factor (TNF)- $\alpha$ $\mathrm{scFv}-\mathrm{Fc}$ was expressed in TKO mutant Arabidopsis thaliana seeds using plant-specific codons. Immunoblotting using a human IgG1 antibody detected the expression of anti-TNF- $\alpha$ proteins in plants. Results from qRT-PCR analysis demonstrated that the time of harvest significantly affected the protein yield and quality. Our results indicate that the Phaseolus vulgaris $\beta$-phaseolin promoter directed anti-TNF- $\alpha$ scFv$\mathrm{Fc}$ expression in $A$. thaliana seeds, with a maximum yield obtained at 20-days of development. Although the yield of anti-TNF- $\alpha$ scFv$\mathrm{Fc}$ protein was not very high, accumulation of recombinant proteins in seeds is an attractive and simple method that can be used to purify biologically active anti-TNF- $\alpha$ scFv-Fc.
\end{abstract}

Key words: A-TNF- $\alpha$; Arabidopsis thaliana; Recombinant protein; Plant seed expression system 


\section{INTRODUCTION}

Tumor necrosis factor (TNF)- $\alpha$ is a member of the TNF superfamily and was initially described as a factor produced by endotoxin-stimulated macrophages that causes hemorrhagic necrosis of tumors (Carswell et al., 1975). TNF- $\alpha$ is a multifunctional proinflammatory cytokine with pleiotropic properties, and is a key mediator of inflammation. Increased TNF- $\alpha$ levels have been reported in many pathological conditions, including the acute phase of cerebral ischemia, periodontal disease (Barone et al., 1997; Zhang et al., 2013), lymphomas, and chronic obstructive pulmonary disease (Petrescu et al., 2010). Anti-TNF- $\alpha$ agents are proven efficacious therapies for rheumatoid arthritis, ankylosing spondylitis, and inflammatory bowel disease (Lin et al., 2008; Karampetsou et al., 2010). Anti-TNF- $\alpha$ has the potential to reduce the risk of developing lymphoma, and is an efficacious and relatively safe treatment that has rarely been associated with serious side effects (Hyrich et al., 2004; Franklin et al., 2005; Borchers et al., 2011).

Although previous studies have described antibody expression and purification (Wang et al., 2015; Yim et al., 2016), yield is often low or barely detectable and the antibody is usually unstable during the purification and storage processes. Furthermore, recombinant scFv-Fc antibodies possess immunologic activity (Jäger et al., 2013). Therefore, an efficient expression system is needed to produce sufficient quantities of recombinant anti-TNF- $\alpha$ antibody for use in preclinical and commercial applications. The biomanufacture of recombinant anti-TNF- $\alpha$ $\mathrm{scFv}-\mathrm{Fc}$ antibodies in plants has several advantages, including the presence of posttranslational modifications similar to those found in eukaryotic cells and the high stability during storage in plant seeds. Furthermore, this manufacturing method produces a safe final product because plants are free from human pathogens and can grow in serum-free media. In this study, we constructed a recombinant anti-TNF- $\alpha$ scFv-Fc vector and expressed anti-TNF- $\alpha$ antibody in Columbia Arabidopsis thaliana seeds. We also investigated the expression level and immunocompetence of anti-TNF $\alpha \mathrm{scFv}$-Fc protein in plant seeds.

\section{MATERIAL AND METHODS}

\section{Materials}

Col-0 A. thaliana (plant-specific glycosylation knockout mutant TKO Arabidopsis), pPhasBar plasmid, and EHA105 Agrobacterium tumefaciens strains were supplied by Jilin Agriculture University Ministry of Education Engineering Research Center of Bioreactor and Pharmaceutical Development. Escherichia coli DH5 $\alpha$ was obtained from Genewiz Biotechnology (Suzhou, China). Restriction endonucleases HindIII, NcoI, and XbaI were purchased from New England Biolabs (Ipswich, MA, USA). Polyvinylidene fluoride (PVDF) membranes were purchased from Millipore. Goat anti-human IgG-HRP was purchased from Abcam (USA). Oligonucleotide primers were acquired from Genewiz Biotechnology (Suzhou, China). All chemicals were of the highest purity available.

\section{Generation of recombinant anti-TNF $\alpha$ scFv-Fc plasmid}

A schematic of the recombinant anti-TNF- $\alpha$ scFv-Fc plasmid is shown in Figure 1. 
In the $\mathrm{pPhasBar}$ plasmid, the seed specific Phaseolus vulgaris $\beta$-phaseolin promoter sequence is located upstream of the CaMV 35S promoter (Figure 1A). A fusion sequence containing the Arabidopsis 2S2 signal peptide sequence and the anti-TNF- $\alpha$ scFv (JC957748.1 and JC957747.1) and Fc (KP783167) sequences, which encoded a 517-amino acid protein, was synthesized, and the coding sequence was optimized according to the preference of plantspesific codon. The fragment was then cloned into the pPhasBar plasmid using the NcoI and $X b a \mathrm{I}$ restriction enzyme sites, downstream of the $P$. vulgaris $\beta$-phaseolin promoter sequence. Recombinant pPhasBar-2S2-anti-TNF- $\alpha$ scFv-Fc plasmid was amplified by PCR using the following forward (5'-CATCATCCATCCATCCAGAGTAC-3') and reverse primers (5'-CATTCCATAAGCCGTCACG-3'). Correct insertion of the gene sequence was confirmed by double enzyme digestion and DNA sequencing.

A

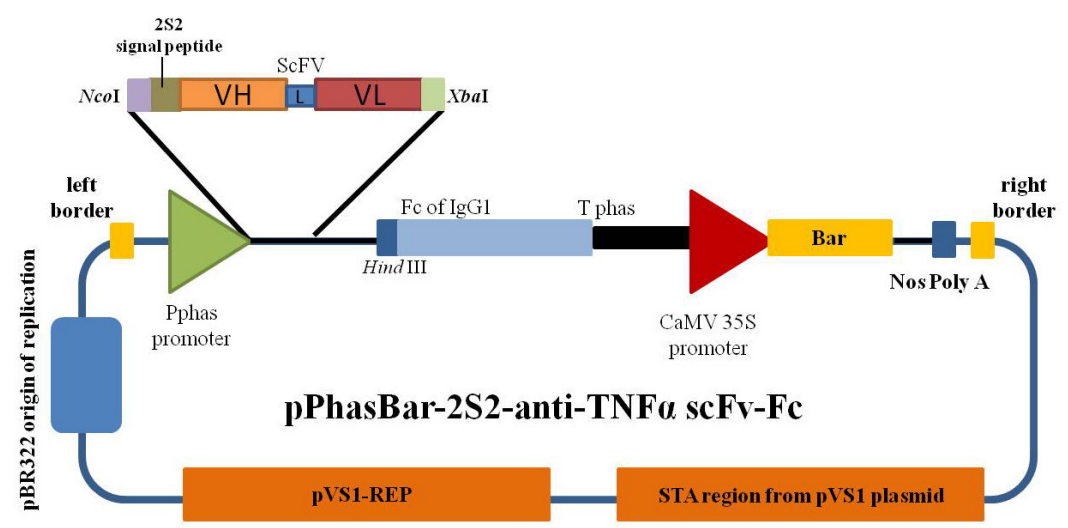

B

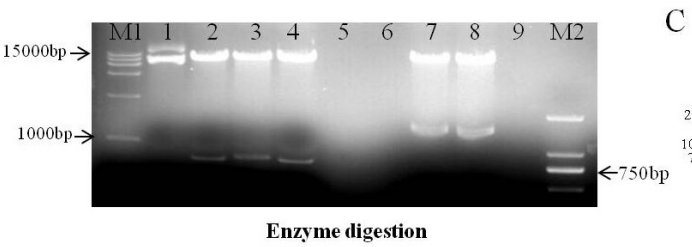

C

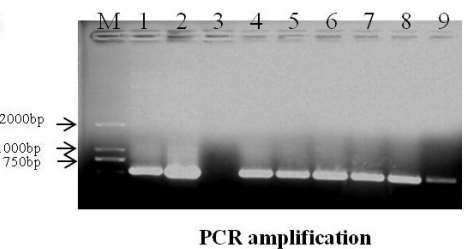

Figure 1. Recombinant plasmid pPhasBar-2S2-anti-TNF- $\alpha$ scFv-Fc was constructed and identified. A. Schematic map of recombinant plasmid pPhasBar-2S2-anti-TNF- $\alpha$ scFv-Fc; B. Agarose gel electrophoresis was performed to analyze the enzyme digested products of recombinant anti-TNF- $\alpha$ scFv-Fc DNA construction; C. Agarose gel electrophoresis was used to analyze the PCR products of anti-TNF $\alpha$ scFv-Fc DNA.

\section{Characterization of anti-TNF- $\alpha \mathrm{scFv}-\mathrm{Fc}$ gene expression in $T K O$ A. thaliana}

The leaves, roots, flowers, and seeds of anti-TNF $\alpha$ scFv-Fc transformed TKO Arabidopsis and control TKO Arabidopsis plants were collected for gene expression analyses. Tissue samples were snap frozen in liquid nitrogen and stored at $-80^{\circ} \mathrm{C}$ until use. Total RNA was isolated from the leaves, roots, flowers, and seeds of TKO Arabidopsis plants using an RNAiso Plus kit (TaKaRa, Japan) following manufacturer protocol. The yield and quality of total RNA were determined using a ND-1000 Spectrophotometer (Pwqlab, Erlangen, Germany) and an Agilent 2100 Bioanalyzer (Agilent Technologies, Palo Alto, CA, USA). 
Quantitative real-time PCR was performed using a Stratagene Mx3000P instrument (Agilent Technologies) with SYBR Green as the fluorescent dye according to the manufacturer protocol (TaKaRa). First-strand cDNA was synthesized from $1 \mathrm{mg}$ total RNA as described above and was then used as a template for quantitative realtime PCR with specific forward (5'-CCAAGGGAGGAGCAGTACAA-3') and reverse (5'-AAGTGTACACCTGAGGCTCC-3') primers. Real-time PCR was performed in a total volume of $25 \mu \mathrm{L}$ using the following cycling conditions: $95^{\circ} \mathrm{C}$ for $5 \mathrm{~min}$, followed by 40 cycles of $94^{\circ} \mathrm{C}$ for $5 \mathrm{~s}, 55^{\circ} \mathrm{C}$ for $20 \mathrm{~s}$, and $72^{\circ} \mathrm{C}$ for $20 \mathrm{~s}$. All reactions were performed in three biological triplicates, and the results were expressed relative to the level of $\beta$-actin expression in each sample by using the $2^{-\Delta \Delta \mathrm{CT}}$ method (Livak and Schmittgen, 2001).

\section{Characterization of anti-TNF- $\alpha$ scFv-Fc production}

Mature TKO Arabidopsis seeds were harvested and $2 \mathrm{mg}$ seeds were snap frozen in liquid nitrogen. After sufficient grinding, seed samples were incubated in $100 \mu \mathrm{L} 50 \mathrm{mM}$ Tris$\mathrm{HCl}(\mathrm{pH} 8.0)$ for $30 \mathrm{~min}$ on ice. The mixture plus $5 \mathrm{X}$ loading buffer was incubated in a boiling water bath for $10 \mathrm{~min}$. After centrifugation, the supernatant was collected and protein samples were separated by $12 \%$ sodium dodecylsulfate polyacrylamide gel electrophoresis (SDSPAGE). Proteins were transferred to PVDF membranes and immuno-blotting was performed using a goat anti-human IgG-HRP antibody. Proteins were visualized using SuperSignal ${ }^{\circledR}$ West Pico Chemiluminescent Substrate (Pierce Chemical Rockford, USA) in the Bio-Rad ECL system. An ELISA was employed to measure the expression of anti-TNF- $\alpha$ scFv-Fc.

\section{RESULTS}

\section{Recombinant anti-TNF $\alpha$ scFv-Fc production and anti-TNF $\alpha$ scFv-Fc transgenic TKO Arabidopsis generation}

The coding region of anti-TNF- $\alpha$ scFv-Fc encoded a 517-amino acid protein, including anti-TNF- $\alpha$ heavy chain, anti-TNF- $\alpha$ light chain, a human IgG1 sequence, and the $2 \mathrm{~S} 2$ signal peptide (Figure 1A). We choose to express anti-TNF- $\alpha$ in TKO Arabidopsis because previous studies have shown that foreign proteins can be expressed in plants (Balaji et al., 2015; Gusman et al., 2015). In this study, we constructed anti-TNF $\alpha$ scFv-Fc expression vector, pPhasBar$2 \mathrm{~S} 2$-anti-TNF $\alpha$ scFv-Fc. (Figure 1B). Next, we used the anti-TNF $\alpha$ scFv-Fc expression vector to transform TKO Arabidopsis via pollen-tube mediated transfection. Recombinant $\mathrm{pPhasBar}$ 2S2-anti-TNF $\alpha \mathrm{scFv}-\mathrm{Fc}$ plasmid contained anti-TNF $\alpha \mathrm{scFv}-\mathrm{Fc}$ under the control of the $P$. vulgaris $\beta$-phaseolin promoter, and the selection marker gene Bar under the control of the CaMV 35S promoter. Transgenic TKO Arabidopsis plants were selected based on 1\% BASTA. The selected lines were analyzed by PCR (Figure 1C). The 530-bp anti-TNF- $\alpha$ specific band was amplified from the anti-TNF $\alpha$ scFv-Fc transgenic lines anti-TNF- $\alpha-1$, anti-TNF- $\alpha-2$, and anti-TNF- $\alpha-3$, but was not detected in Col-0 and CK plants (transgenic line with pPhasBar but without anti-TNF- $\alpha \mathrm{scFv}-\mathrm{Fc}$ expression cassette). These results suggests that foreign genes had successfully inserted into the genome of TKO A. thaliana.

\section{Anti-TNFa scFv-Fc gene specific expression in seeds}

Transgenic molecular markers, such as bar and $B t$, can be used for the identification of 
transgenic plants, and marker-assisted selection of many economic plants. The identification of bar-resistant transgenic molecular markers is a convenient method in selection and breeding. The CaMV 35S promoter and bar gene, which were located between Left Border (LB) and Right Border (RB) on the vector, were transferred together into the Arabidopsis genome. To determine the pattern of tissue-specific gene-expression, qRT-PCR was used to evaluate bar and anti-TNF- $\alpha \mathrm{scFv}-\mathrm{Fc}$ gene expression in different tissues. Figure 2 shows that bar is expressed in the roots, stems, and flowers, and during three periods of seed development $(5,10$, and 20 days). No difference was observed in the gene expression profile in different tissues at different periods of seed development under the control of the CaMV35S promoter (Figure 2A). Figure 2B shows the expression of anti-TNF- $\alpha$ scFv-Fc in various tissues and at various tissue development stages. We were unable to detect anti-TNF- $\alpha$ scFv-Fc gene expression in the roots, stems, or flowers. Anti-TNF- $\alpha \mathrm{scFv}-\mathrm{Fc}$ was found to be expressed in seeds, with the highest relative abundance observed in the 20-day-old seeds as compared to the 5- and 10-day-old seeds $(\mathrm{P}<0.05)$. Anti-TNF- $\alpha \mathrm{scFv}-\mathrm{Fc}$ was expressed at higher levels in the 10-day-old seeds than in the 5-day-old seeds $(\mathrm{P}<0.05)$ (Figure 2B). This demonstrates that seed-specific expression of anti-TNF- $\alpha \mathrm{scFv}-\mathrm{Fc}$ is driven by the $P$. vulgaris $\beta$-phaseolin promoter. In particularly, 20-day-old seeds from transgenic Arabidopsis plants contained the highest level of anti-TNF- $\alpha \mathrm{scFv}-\mathrm{Fc}$ expression, indicating that the most appropriate time to harvest the protein is at the mature stage.

A

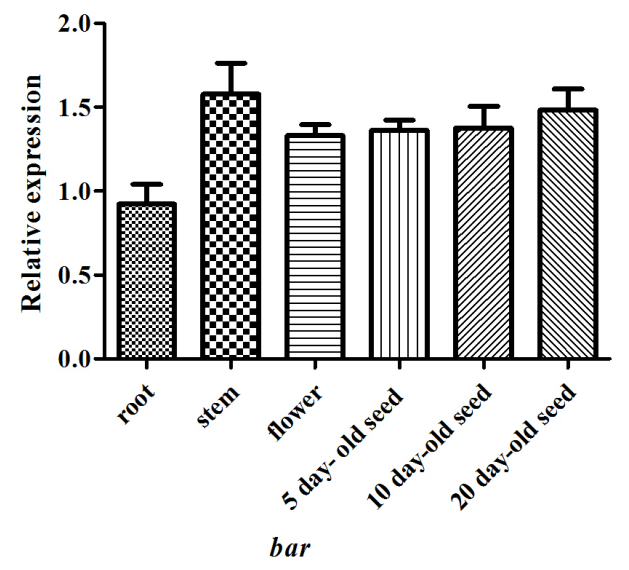

B

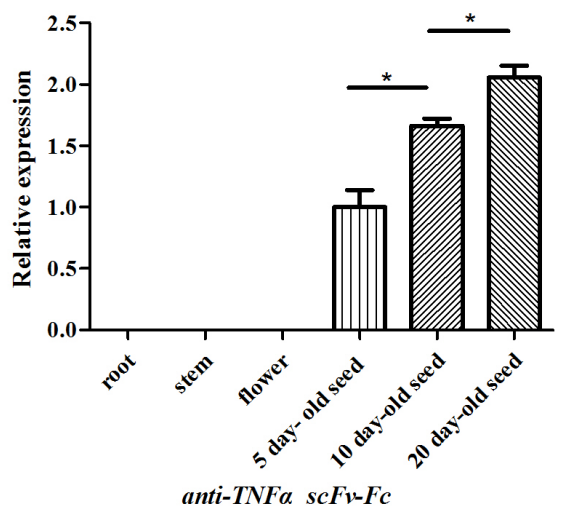

Figure 2. qRT-PCR analysis of gene expression. A. bar expression in different tissues; B. anti-TNF- $\alpha$ scFv-Fc expression in different tissues.

\section{Characterization of anti-TNF- $\alpha$ scFv-Fc protein expression in TKO A. thaliana}

Figure 3A and B show the results of SDS-PAGE and western blot analysis of antiTNF- $\alpha$ scFv-Fc proteins from harvested Arabidopsis seeds. Anti-TNF- $\alpha$ scFv-Fc protein could not be easily identified by SDS-PAGE, although it was clear it could be detected using an anti-IgG antibody. The size of the fusion protein was $\sim 55 \mathrm{kDa}$, as predicted. No anti-TNF- $\alpha$ 
scFv-Fc protein expression was observed in TKO Arabidopsis seeds. This indicates that the $P$. vulgaris $\beta$-phaseolin promoter and the $2 \mathrm{~S} 2$ signal peptide induced the expression of antiTNF- $\alpha$ scFv-Fc in transgenic TKO Arabidopsis seeds. Thus, recombinant anti-TNF- $\alpha$ scFv$\mathrm{Fc}$ protein was successfully expressed in plant seeds.

A

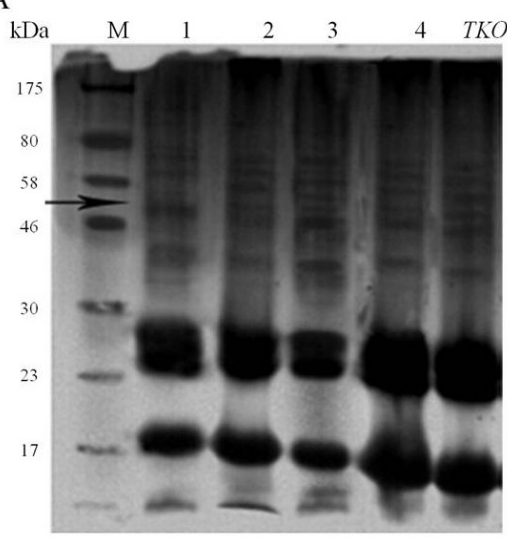

B

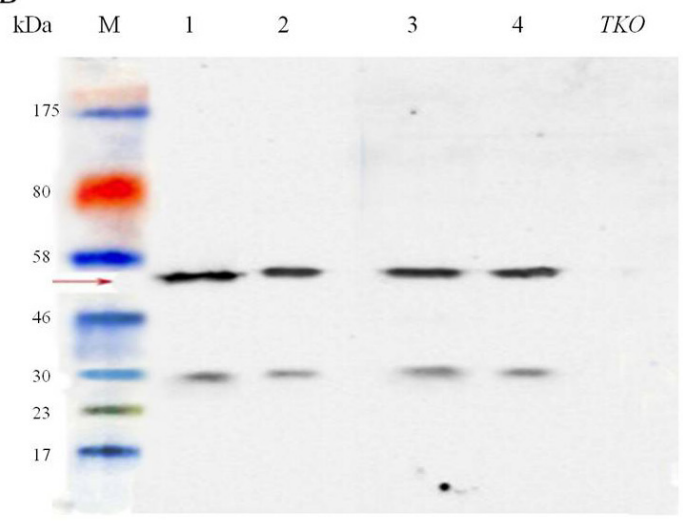

Figure 3. Detection of recombinant anti-TNF $\alpha$ scFv-Fc protein. A. SDS-PAGE detection of recombinant antiTNF- $\alpha$ scFv-Fc protein; B. Western blot detection of recombinant anti-TNF- $\alpha$ scFv-Fc protein.

\section{Assessment of anti-TNF- $\alpha$ scFv-Fc protein expression}

To evaluate the recombinant protein content and activity in this seed expression system, biobarcode amplification (BCA) and ELISA were used to assess the concentrations of total soluble protein and anti-TNF- $\alpha$ scFv-Fc protein, respectively, in transgenic Arabidopsis. Protein concentration is shown in Figure 4. For T-2 generation 5-day-old transgenic Arabidopsis seeds, the protein concentration was $0.269 \pm 0.0569 \mathrm{mg} / \mathrm{g}$ seed, and the amount of soluble functional antibody protein accounts for $0.122 \pm 0.026 \%$ of the total soluble protein. The mean content increased to $0.365 \pm 0.0695 \mathrm{mg} / \mathrm{g}$ in T-3 generation seeds. For 10-day-old transgenic Arabidopsis seeds, the concentration of anti-TNF- $\alpha$ scFv-Fc protein was increased in both T-2 $(0.364 \pm 0.0754 \mathrm{mg} / \mathrm{g})$ and T-3 $(0.501 \pm 0.0785 \mathrm{mg} / \mathrm{g})$ generation seeds. In welldeveloped mature seeds (20-day stage), the accumulation of recombinant protein peaked with a mean capacity of $0.453 \pm 0.085$ and $0.634 \pm 0.0876 \mathrm{mg} / \mathrm{g}$ in T-2 and T-3 generation lines, respectively. Recombinant protein from T-3 generation mature seeds accounted for $0.32 \pm$ $0.046 \%$ of the total soluble protein. The increased level of functional protein observed in T-3 generation transgenic Arabidopsis lines demonstrate that pure strain lines generate higher levels of purified protein than do T-2 generation seeds.

\section{DISCUSSION}

The use of plants to produce pharmaceutically important and commercially valuable proteins is a relatively recent concept (Daniell et al., 2001). As the demand for safe and inexpensive means for mass production of recombinant pharmaceutical proteins increases, the 


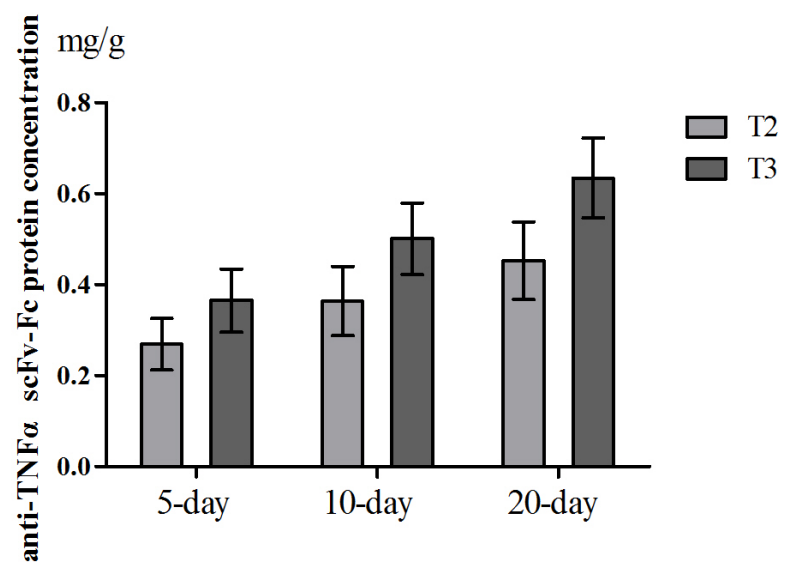

Figure 4. Level of recombinant anti-TNF $\alpha \mathrm{scFv}-\mathrm{Fc}$ protein expression.

production of complex mammalian proteins in transformed plants or plant suspension cells, such as HIV-neutralizing antibody 2G12B expressed in tobacco and rice (Ma et al., 2015; Sack et al., 2015; Vamvaka et al., 2016), human interleukin-10 fusions expressed in tobacco cell suspension cultures (Kaldis et al., 2013), is desirable. Because plants are suitable for the large scale production of pharmaceutical proteins, and the expressed proteins are functional and almost indistinguishable from their mammalian counterparts, they will be available in significantly larger amounts, and a cost-effective basis (Sharma and Sharma, 2009). Transgenic plants can also produce organs that are rich in recombinant biopharmaceuticals for long-term storage. They can be used for cost-effective production and are easy to scale up for mass production. In addition, post-translation modifications are also performed as well as they are in mammalian production systems. Because $\mathrm{N}$-glycosylation of peptides was found in TKO mutant $A$. thaliana seeds (Loos et al., 2011), we selected these mutants for use in antibody expression.

High levels of recombinant protein expression are required for the production of proteins for pharmaceutical use. To obtain high levels of recombinant anti-TNF- $\alpha$ scFv-Fc protein, the signal peptide of the $2 \mathrm{~S} 2$ seed storage protein gene of $A$. thaliana was inserted upstream of the anti-TNF- $\alpha$ scFv-Fc encoding sequence into the pPhasBar-2S2-anti-TNF $\alpha$ $\mathrm{scFv}-\mathrm{Fc}$ plasmid. However, in contrast to the results of previous studies, we were unable to generate high levels of expressed protein $(0.32 \pm 0.046 \%)$. This may be associated with the low transcriptional activity of the recombinant anti-TNF- $\alpha$ scFv-Fc gene. However, we aim to improve the cultivation methods and protein expression system to gain high levels of recombinant proteins. An unexpected anti-TNF- $\alpha \mathrm{scFv}-\mathrm{Fc}$ protein band of $30-\mathrm{kDa}$ was observed, which we suggest may be associated with protein degradation or a different protein conformation. Degradation leads to low yield of pharmaceutical protein products, and affects the biological activity of proteins (Rita Costa et al., 2010; Hehle et al., 2015). Degradation of foreign proteins is a significant challenge for their cost-effective production, regardless of the transient expression system used (Hehle et al., 2015). Researchers have noted that optimized cultivation conditions will help to reduce the degradation of recombinant proteins (Ishikawa et al., 2010; Rita Costa et al., 2010). We also aim to address this problem in our future research. 
In summary, we successfully constructed a plant seed recombinant anti-TNF- $\alpha$ scFvFc vector and expressed foreign recombinant anti-TNF- $\alpha$ scFv-Fc protein in Arabidopsis seeds. The 55-kDa protein was characterized using SDS-PAGE and western blotting. AntiTNF- $\alpha$ scFv-Fc expression in Arabidopsis seeds is a variable method that can be used for the highly efficient expression and potential commercial production of pharmaceutical antiTNF- $\alpha$ proteins.

\section{Conflicts of interest}

The authors declare no conflict of interest.

\section{ACKNOWLEDGMENTS}

Research supported by the National High Technology Research and Development Program of China ("863" Program) (Grant \#2011AA100606), the National Natural Science Foundation of China (Grant \#31101172, \#31101091, and \#31501366), the Science and Technology Development Project of Jilin Province (\#20150104027NY), the Department of Human Resources and Social Security of Jilin Province (\#Y3D1071001).

\section{REFERENCES}

Balaji P, Satheeshkumar PK, Venkataraman K and Vijayalakshmi MA (2015). Expression of anti-tumor necrosis factor alpha $(\mathrm{TNF} \alpha)$ single-chain variable fragment $(\mathrm{scFv})$ in Spirodela punctata plants transformed with Agrobacterium tumefaciens. Biotechnol. Appl. Biochem. 17: 1-8 10.1002/bab.1373.

Barone FC, Arvin B, White RF, Miller A, et al. (1997). Tumor necrosis factor-alpha. A mediator of focal ischemic brain injury. Stroke 28: 1233-1244. http://dx.doi.org/10.1161/01.STR.28.6.1233

Borchers AT, Leibushor N, Cheema GS, Naguwa SM, et al. (2011). Immune-mediated adverse effects of biologicals used in the treatment of rheumatic diseases. J. Autoimmun. 37: 273-288. http://dx.doi.org/10.1016/j.jaut.2011.08.002

Carswell EA, Old LJ, Kassel RL, Green S, et al. (1975). An endotoxin-induced serum factor that causes necrosis of tumors. Proc. Natl. Acad. Sci. USA 72: 3666-3670. http://dx.doi.org/10.1073/pnas.72.9.3666

Daniell H, Streatfield SJ and Wycoff K (2001). Medical molecular farming: production of antibodies, biopharmaceuticals and edible vaccines in plants. Trends Plant Sci. 6: 219-226. http://dx.doi.org/10.1016/S1360-1385(01)01922-7

Franklin JP, Symmons DP and Silman AJ (2005). Risk of lymphoma in patients with RA treated with anti-TNFalpha agents. Ann. Rheum. Dis. 64: 657-658. http://dx.doi.org/10.1136/ard.2005.035311

Gusman GS, Campana PR, Castro LC, Castilho RO, et al. (2015). Evaluation of the Effects of Some Brazilian Medicinal Plants on the Production of TNF- $\alpha$ and CCL2 by THP-1 Cells. Evid. Based Complement. Alternat. Med. 497123 : 1-11. http://dx.doi.org/10.1155/2015/497123

Hehle VK, Lombardi R, van Dolleweerd CJ, Paul MJ, et al. (2015). Site-specific proteolytic degradation of IgG monoclonal antibodies expressed in tobacco plants. Plant Biotechnol. J. 13: 235-245. http://dx.doi.org/10.1111/pbi.12266

Hyrich KL, Silman AJ, Watson KD and Symmons DP (2004). Anti-tumour necrosis factor alpha therapy in rheumatoid arthritis: an update on safety. Ann. Rheum. Dis. 63: 1538-1543. http://dx.doi.org/10.1136/ard.2004.024737

Ishikawa T, Ito T, Endo R, Nakagawa K, et al. (2010). Influence of $\mathrm{pH}$ on heat-induced aggregation and degradation of therapeutic monoclonal antibodies. Biol. Pharm. Bull. 33: 1413-1417. http://dx.doi.org/10.1248/bpb.33.1413

Jäger V, Büssow K, Wagner A, Weber S, et al. (2013). High level transient production of recombinant antibodies and antibody fusion proteins in HEK293 cells. BMC Biotechnol. 13: 52-71. http://dx.doi.org/10.1186/1472-6750-13-52

Kaldis A, Ahmad A, Reid A, McGarvey B, et al. (2013). High-level production of human interleukin-10 fusions in tobacco cell suspension cultures. Plant Biotechnol. J. 11: 535-545. http://dx.doi.org/10.1111/pbi.12041

Karampetsou MP, Liossis SN and Sfikakis PP (2010). TNF- $\alpha$ antagonists beyond approved indications: stories of success and prospects for the future. QJM 103: 917-928. http://dx.doi.org/10.1093/qjmed/hcq152

Lin J, Ziring D, Desai S, Kim S, et al. (2008). TNFalpha blockade in human diseases: an overview of efficacy and safety. Clin. Immunol. 126: 13-30. http://dx.doi.org/10.1016/j.clim.2007.08.012 
Livak KJ and Schmittgen TD (2001). Analysis of relative gene expression data using real-time quantitative PCR and the 2(-Delta Delta C(T)) Method. Methods 25: 402-408. http://dx.doi.org/10.1006/meth.2001.1262

Loos A, Van Droogenbroeck B, Hillmer S, Grass J, et al. (2011). Production of monoclonal antibodies with a controlled N-glycosylation pattern in seeds of Arabidopsis thaliana. Plant Biotechnol. J. 9: 179-192. http://dx.doi.org/10.1111/ j.1467-7652.2010.00540.x

Ma JK, Drossard J, Lewis D, Altmann F, et al. (2015). Regulatory approval and a first-in-human phase I clinical trial of a monoclonal antibody produced in transgenic tobacco plants. Plant Biotechnol. J. 13: 1106-1120. http://dx.doi. org/10.1111/pbi.12416

Petrescu F, Voican SC and Silosi I (2010). Tumor necrosis factor-alpha serum levels in healthy smokers and nonsmokers. Int. J. Chron. Obstruct. Pulmon. Dis. 5: 217-222.

Rita Costa A, Elisa Rodrigues M, Henriques M, Azeredo J, et al. (2010). Guidelines to cell engineering for monoclonal antibody production. Eur. J. Pharm. Biopharm. 74: 127-138. http://dx.doi.org/10.1016/j.ejpb.2009.10.002

Sack M, Rademacher T, Spiegel H, Boes A, et al. (2015). From gene to harvest: insights into upstream process development for the GMP production of a monoclonal antibody in transgenic tobacco plants. Plant Biotechnol. J. 13: 1094-1105. http://dx.doi.org/10.1111/pbi.12438

Sharma AK and Sharma MK (2009). Plants as bioreactors: Recent developments and emerging opportunities. Biotechnol. Adv. 27: 811-832. http://dx.doi.org/10.1016/j.biotechadv.2009.06.004

Vamvaka E, Twyman RM, Murad AM, Melnik S, et al. (2016). Rice endosperm produces an underglycosylated

and potent form of the HIV-neutralizing monoclonal antibody 2G12. Plant Biotechnol. J. 14: 97-108.

Wang D, Guo Y, Li Y, Li W, et al. (2015). Detection of CD133 expression in U87 glioblastoma cells using a novel antiCD133 monoclonal antibody. Oncol. Lett. 9: 2603-2608.

Yim SS, Choi JW, Lee RJ, Lee YJ, et al. (2016). Development of a new platform for secretory production of recombinant proteins in Corynebacterium glutamicum. Biotechnol. Bioeng. 113: 163-172. http://dx.doi.org/10.1002/bit.25692

Zhang S, Barros SP, Moretti AJ, Yu N, et al. (2013). Epigenetic regulation of TNFA expression in periodontal disease. $J$. Periodontol. 84: 1606-1616. 